\title{
UN PARTİKÜL BOYUTUNUN EKMEĞİN FİZİKSEL ÖZELLİKLERİ VE RAF ÖMRÜ ÜZERİNE ETKİSI
}

\author{
Sultan Arslan Tontul*, Hümeyra Çetin Babaoğlu \\ Selçuk Üniversitesi, Ziraat Fakültesi, Gıda Mühendisliği Bölümü, 42130 Konya, Türkiye
}

Geliş / Received: 20.02.2019; Kabul / Accepted: 10.09.2019; Online bask1 / Published online: 19.09.2019

Arslan-Tontul, S., Çetin-Babaoğlu, H. (2019). Un partikül boyutunun ekmeğin fiziksel özellikleri ve raf ömrü üzerine etkisi. GIDA (2019) 44 (5): 898-906 doi: 10.15237/gida.GD19045

Arslan-Tontul, S., Cetin-Babaoğlu, H. (2019). Effect of flour particle size on physical properties and shelf life of bread. GIDA (2019) 44 (5): 898-906 doi: 10.15237/gida.GD19045

\section{ÖZ}

Bu çalışmada farklı partikül boyutuna sahip unlar ile üretilen ekmeklerin depolanması sırasında meydana gelen fiziksel değişimlerin belirlenmesi ve bayatlamanın kinetik olarak modellenmesi amaçlanmıştır. Farinograf ve ekstensograf testleri sonucunda ekmek hamurlarının un partikül boyutunun azaltılmasinin, hamurun reolojik özelliklerini geliştirdiği tespit edilmiştir. Ekmek kabuğunun L* parlaklık, 39.83 ile 53.28 değeri arasında değişmekle birlikte partikül boyutunun azaltılması ekmek parlaklık değerini düşürmüştür. Tekstür profil analizi sonucunda depolanan ekmeklerin sertlik değerlerinin yaklaşık olarak 2.7 kat arttı̆̆ı ve en yüksek artışın ise $150 \mu$ altı un partiküllerinden üretilen ekmek örneklerinde gerçekleştiği belirlenmiştir. Depolama süresince ekmeklerde nem kaybı değerleri kontrol, 150-250 $\mu$ arası ve $150 \mu$ altı örnekler için sırasıyla \%14.92, 0.53 ve 6.72 olarak tespit edilmiştir. Ekmek bayatlamasının Avrami kinetik modele uygunluğunun değerlendirildiği hesaplamalarda ise 1.85 ile en yüksek $n$ değerini ve 0.13 ile en düşük $\mathrm{k}$ değerini düşük partikül boyutlu unlar kullanılarak üretilen ekmek örneklerinin aldığı belirlenmiştir.

Anahtar kelimeler: Ekmek bayatlaması, bayatlama kinetiği, Avrami, partikül boyutu, tekstür

\section{EFFECT OF FLOUR PARTICLE SIZE ON PHYSICAL PROPERTIES AND SHELF LIFE OF BREAD}

\begin{abstract}
In this study, it is aimed to determine the physical changes, occurring during the storage of the breads produced with different particle size of flours and kinetic modelling of staling. The farinograph and extensograph tests of the doughs indicated that reducing the particle size of flours improved the rheological properties of the dough. According to color results, the L* brightness of the bread crust ranged from 39.83 to 53.28 and the lowest value was determined in the bread produced by fine milled wheat flour. As a result of the texture profile analysis, the hardness values of the breads increased approximately 2.7 times and the highest increase was detected in the bread samples produced from fine milled wheat flour. Moisture loss during storage were 14.92, 0.53 and $6.72 \%$ for the control sample, breads produced with flour particle size of $150-250 \mu$ and $<150 \mu$, respectively. Avrami kinetic model suggested that the highest $n$ value with 1.85 and the lowest $\mathrm{k}$ value with 0.13 were obtained from the bread samples produced with low particle size flours.
\end{abstract}

Keywords: Bread staling, Staling kinetic, Avrami, particle size, texture

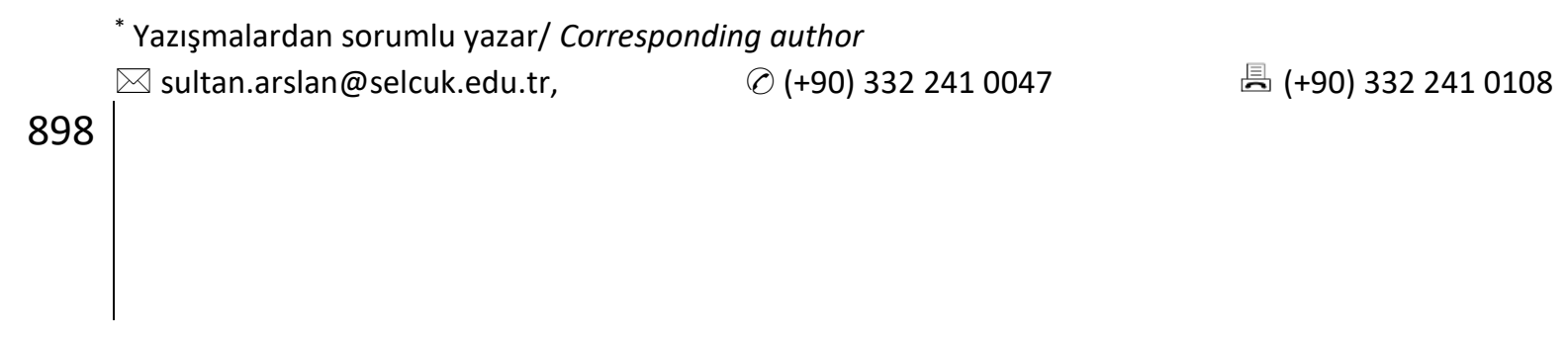




\section{GİRIŞ}

Ekmek, ülkemiz başta olmak üzere birçok toplumda ucuz ve kolay ulaşılabilir olması ve besin ögelerini dengeli bir şekilde içermesi nedenleriyle temel besin kaynağı olarak kabul edilmektedir. Ancak taze ekmeğin çok kısa olan raf ömrü (1-2 gün), ekmeğin tüketilebilirliğini doğrudan etkilemektedir.

Günümüzde ekmek bayatlama mekanizması tam olarak aydınlatılamamış olmakla birlikte başta nişasta granülünün kristalizasyonu olmak üzere nişasta-gluten interaksiyonları ve ekmek içeriği nem göçü gibi birçok faktörün rol aldığ1 kompleks bir olay olarak tanımlanmaktadır (Fadda, Sanguinetti vd., 2014). Bayatlama fiziksel bir bozulma olup ürünün raf ömrünü doğrudan etkilemekte ve ekmeğin yenme kalitesini ciddi oranda azaltmaktadir. Bayatlama sonucu tüketilemeyen ekmek, yüksek miktarda ekonomik kayıplara neden olmaktadır (Limanond vd., 2002; Smith ve Johansson, 2004). Toprak Mahsulleri Ofisi'nin verilerine göre günde yaklaşı 5 milyon ekmek çöpe atılmaktadır. 2010 yılında yapılan bir araştırmaya göre İngiltere'de yıllık olarak üretilen 39 milyon ekmeğin yaklaşı 10 milyonunun, bayatlama temelli fiziksel bozulmalar sonucu tüketilemeyerek israf edildiği bildirilmiştir (Amigo vd., 2016). Başka bir çalışmada ise Amerika Birleşik Devletleri, Meksika ve Latin Amerika ülkelerinde yıllık 450 milyon ton tortilla ekmeği üretilmekte ve bunun yaklaşı olarak \%4’ü (18 milyon ton) bayatlama nedeniyle tüketilmemektedir (Limanond vd., 2002). Günümüzde gıda endüstrisi ve bilimi, ekmek bayatlamasını geciktirici katk1 maddelerinin geliştirilmesi, proses basamaklarının iyileştirilmesi ve bu sayede israf kaynaklı para, enerji ve gida kaybının azaltılması konuları üzerine yoğun çalışmalar yürütmektedir (Amigo vd., 2016).

Ekmek bayatlaması doğrudan nişasta retrogradasyonu ile ilişkili olup ilerleyen aşamalarda ise ortamda bulunan gluten ile interaksiyonun artmas1 sonucunda geri dönüşümsüz bir hal almaktadır. Nişasta, sulu ortamda 1sıtıldığ 1 zaman su alarak şişmekte ve belirli bir sicaklik noktasindan sonra jelatinize olmaktadır. Jelatinize olmuş nişasta erime sicaklığının altında bir dereceye kadar soğutulduğunda fiziksel yapısı bozulan amiloz ve amilopektin fraksiyonları yoğun bir şekilde kümeleşerek gida matrisinin viskozitesinin artmasına ve jelin sıkılaşmasına neden olmaktadır. $\mathrm{Bu}$ olgunun tamamina birden retrogradasyon adı verilmekte olup gida endüstrisi için büyük önem taşımaktadır (Atwell vd., 1988; Amigo vd., 2016).

Bayatlama ekmek içi ve dışında ayrı ayrı gerçekleşmektedir. Bayatlama boyunca ekmek içerisi sertlik kazanırken ekmek kabuğu ise tam tersine yumuşamaktadır. Ekmek kabuğu higroskopik özellikte birçok madde içerdiğinden hızlı nem çekme özelliğine sahiptir. Dolayısı ile bayatlama sırasında ekmek içerisinde bulunan su, sürekli ekmek kabuğuna difüze olmaktadır. Ekmek içerisinden kabuğa su geçişi, depolamanın son zamanlarında artmakta ve biyopolimer ăg içerisindeki su miktarının azalmasıyla hızlanmaktadır (Ercan ve Özkaya, 1985). Nişasta granülünün amiloz fraksiyonunda gelişen retrogradasyon çok hızlı olup, neredeyse firnn çıkışından sonra bir kaç saatte tamamlanırken, bu süre amilopektin için haftaları bulabilmektedir (Leon vd., 2006).

Günümüzde, fazla miktarda üretimi yapılan ekmek gibi firıncllık ürünleri ekonomiye önemli bir gelir katkısı ve iş gücü sağlamaktadır. Ekmeğin satın alınma tercihini etkileyen en temel özellik tazeliği olduğundan, yenilebilir kalitesinin kaybedilmeden uzun bir raf ömrü sağlanması gıda bilimi ve endüstrisi açısından önemli bir konudur. Ekmek bayatlaması ile ilgili çalışmalar çok uzun yıllardır süregelmekle birlikte unun partikül boyutunun bayatlama üzerine etkisinin araştırıldığı çok sınırlı sayıda çalışma bulunmaktadır. Bu çalısmalarda genellikle jet değirmenlerde çok küçük mikron boyutuna öğütülen un örneklerinin ekmek kalitesi üzerine etkileri incelenmiştir (Protonotariou vd., 2015; Vouris vd., 2018). Bu çalışmada 250-150 $\mu$ arası ve $150 \mu$ üstü partikül boyutuna sahip unlar ile üretilen ekmeklerin depolanmasi sirasinda meydana gelen fiziksel değişimlerin belirlenmesi ve bayatlamanın kinetik olarak modellenmesi amaçlanmıştır. 


\section{MATERYAL ve YÖNTEM}

\section{Materyal}

Araştırmada kullanılan ekmeklik un (protein $\% 12.2$, yă̆ $\% 1.5$, kül \%0.8) Söke Un Fabrikası'ndan (Aydın, Türkiye) temin edilmiştir. Ekmeklik un 250 ve $150 \mu$ boyutundaki eleklerden (Retsch, Haan, Almanya) elenerek partikül boyutu ayarlanmıştır. Ekmek üretiminde kullanılan diğer hammaddeler (tuz, maya ve su) yerel marketlerden temin edilmiştir.

\section{Yöntem \\ Ekmek Üretimi}

Ekmek üretimi için $1000 \mathrm{~g}$ un, $40 \mathrm{~g}$ maya, $15 \mathrm{~g}$ tuz ve farinograf cihazında her bir un partikül boyutu için belirlenen miktarda su (kontrol $540 \mathrm{~mL}, 150$ $250 \mu$ aras $530 \mathrm{~mL}$ ve $150 \mu$ alt1 $550 \mathrm{~mL}$ ) hamur yoğurma makinesine (Major, Kenwood, İngiltere) aktarılarak 5 dak yoğrulmuştur. Yoğrulduktan sonra makineden alınan hamur 30 dak kitle fermantasyonuna bırakılmıştır. Fermantasyon sonunda rol ekmek üretmek üzere $100 \mathrm{~g}$ ağırlığında hamurlar kesilerek, küresel şekil verilmiş ve 15 dak ara fermantasyon uygulanmıştır. Süre sonunda tekrar elle şekil verilerek havalandırılan hamurlar tavaya alınmış ve $30^{\circ} \mathrm{C}$ 'de $\% 80$ nem altında 1 saat süre ile son fermantasyona birakılmışır. Fermantasyon sonunda tavalar $250^{\circ} \mathrm{C}^{\prime}$ 'de döner ekmek pişirme firınında (Fimak, Konya, Türkiye) 20 dak pişirilerek ekmek üretimi gerçekleştirilmiştir. Pişirme sonunda $150 \mu$ altı, $150-250 \mu$ arası ve eleme yapilmamış un pasajı olarak (kontrol) toplamda üç farklı boyutta un kullanılarak ekmek üretimi gerçekleştirilmiştir (Elgün ve Ertugay, 2002).

\section{Hamurun reolojik özelliklerinin belirlenmesi}

Farklı boyutlarda un kullanilarak hazırlanan ekmek hamurlarının su absorpsiyonu, gelişme süresi, stabilitesi ve yumuşama derecesi farinograf cihazi ile (Brabender OHG, Duisburg, Almanya); uzamaya karşı gösterdiği direnç, uzama kabiliyeti ve enerji değeri gibi diğer reolojik özellikleri ise ekstensograf cihaz1 (Brabender OHG, Duisburg, Almanya) ile belirlenmiştir (AACC, 2000).

\section{Spesifik hacim analizi}

Pişirilen ekmeklerin spesifik hacim değerleri, kolza tohumu ile yer değiştirme prensibine göre ölçülen hacmin, ekmeğin ağırlığına oranlanması sonucu $\mathrm{cm}^{3} / \mathrm{g}$ olarak hesaplanmıstır (Ho vd., 2013).

\section{Renk analizi}

Ekmeklerin rengi, renk ölçer (Chroma meter CR400, Konica Minolta, Japonya) kullanilarak, ekmek kabuğu ve içinde ayrı ayrı 3 farklı noktadan $L^{*}, a^{*}$ ve $b^{*}$ değerlerinin ölçülmesi ile belirlenmiştir.

\section{Nem kaybr}

Ekmek örneklerin nem kayb1 değeri depolama başlangıcında (0. gün) ve sonunda (6. gün) alınan örneklerin kurumadde miktarlarının oranlanması ile \% olarak hesaplanmıştır (Correa ve Ferrero, 2015).

\section{Tekstür analizi}

Ekmeklerin tekstür profil analizi (TPA), tekstür analiz cihazı (TA, Stable Microsystems, Godalming, Surrey, İngiltere) kullanilarak gerçekleştirilmiştir. Pişirme sonrasında ve 6 gün oda sicaklığında depolanan ekmek örnekleri, 2.5 $\mathrm{mm}$ genişliğinde dilimlenmiş ve ekmek içerisinin sertlik, kohezif yapışkanlık, elastikiyet, sakızımsılık, çiğnenebilirlik ve esneklik özelliklerinde meydana gelen değişimler takip edilmiştir. Analiz sırasında $12.5 \mathrm{~mm}$ çapinda silindirik prob ve 5 kg'llk yük hücresi kullanılmıştır. TPA test öncesi prob hızı $2 \mathrm{~mm} / \mathrm{s}$, test hiz1 $3 \mathrm{~mm} / \mathrm{s}$, test sonrasi hiz1 $3 \mathrm{~mm} / \mathrm{s}$, bekleme süresi $5 \mathrm{~s}$, tetik kuvveti $10 \mathrm{~g}$ ve deformasyon oranı ise $\% 50$ olacak şekilde ayarlanmıştır (Gambaro vd., 2002).

\section{Bayatlama kinetiği}

Ekmek örneklerinin bayatlama kinetiği, Avrami matematik modeli kullanılarak Eşitlik 1'de verilen formüle göre belirlenmiştir. Pişirilen ekmek örnekleri 6 günlük süre boyunca oda sıcaklığında depolanmış ve her depolama gününde TPA cihazı kullanılarak ekmek içi sıkılık değerleri tespit edilmiştir. Analiz sırasında $12.5 \mathrm{~mm}$ silindirik prob ve $5 \mathrm{~kg}$ yük hücresi kullanılmıştır. TPA test hiz1 $1,7 \mathrm{~mm} / \mathrm{s}$ ve deformasyon oran1 $\% 40$ olacak şekilde ayarlanmıştır (AACC, 2000). Model sonunda hesaplanan $\mathrm{k}$ ve $\mathrm{n}$ değerlerinin düşük olması, ekmeklerin daha geç bayatladığı anlamına 
gelmektedir (Armero ve Collar, 1998; Russell, 1983).

$\theta=\frac{T_{\infty}-T_{t}}{T_{\infty}-T_{0}}=e^{-k t^{n}} \quad$ Eşitlik (1)

Ө: Kristalizasyon derecesi

$\mathrm{T}_{0}$ : Pişirme sonunda ekmeklerin sıkılık derecesi

$\mathrm{T}_{\mathrm{t}}$ : Ekmeklerin t zamanındaki sıkılık derecesi

$T_{\infty}$ : Depolama sonundaki sıkılık değeri

k: Reaksiyon sabiti

n: Avrami katsayisi

\section{Istatistiksel analizler}

Ekmek üretimi iki tekerrürlü ve analizler ise iki paralel halinde yapılmıştır. Analiz sonucunda elde edilen verilere varyans analizi ve önemli bulunan faktörlere ise Duncan Çoklu Karşılaştırma Testi uygulanmıştır. Tüm istatistik hesaplamalar SAS istatistik programı ile gerçekleştirilmiş olup değerler ortalama \pm standart sapma şeklinde düzenlenmiştir.

\section{TARTIŞMA ve BULGULAR}

Farklı un partikül boyutunun ekmek hamur reolojisi üzerine etkisi

Kontrol, $150-250 \mu$ arası ve $150 \mu$ altı un örnekleri ile hazırlanan ekmek hamurlarının farinograf ve ekstensograf cihazında belirlenen reolojik özellikleri Çizelge 1'de verilmiştir. Farinograf değerleri incelendiğinde 150-250 $\mu$ aras1 partikül boyutuna sahip unlar ile hazırlanan hamur formülasyonunun, su absorbsiyon değerinin daha düşük olduğu görülmektedir. Buna karşın hiç eleme yapılmamış kontrol unu ve daha küçük boyuttaki un formülasyonlarının su absorbsiyon değerleri benzer şekilde ölçülmüştür. Bu durumun nedeni ise partikül boyutunun küçülmesi sırasında nişasta granülünün daha fazla zedelenmesi ve artan yüzey alanı ile birlikte su tutma kapasitesinin de artmasıdır. Yapılan bir çalışmada tam buğday unu jet değirmenlerde öğütülerek farklı partikül boyutlarına sahip tam buğday unları elde edilmiş ve bu unların reolojik özellikleri araştırılmıştır. Araştırma sonucunda partikül boyutunun küçülmesiyle birlikte yüzey alanının arttığı ve bunun örneklerin su tutma kapasitesini arttırıcı bir rol oynadığ1 bildirilmiştir (Protonotariou vd., 2015). Farklı ögütme teknikleri ile elde edilen ekmeklik unların partikül boyutu; unun su absorbsiyon yeteneği, zedelenmiş nişasta miktarı, jelleşme özellikleri ve hamurun reolojik özellikleri üzerine doğrudan etkili olmaktadır (Vouris vd., 2018).

Çizelge 1. Farklı un partikül boyutunun ekmek hamurunun reolojik özellikleri üzerine etkisi Table 1. The effect of flour particle size on reological properties of bread dough

\begin{tabular}{|c|c|c|c|c|c|c|}
\hline \multirow[b]{2}{*}{$\begin{array}{l}\text { Un boyutu } \\
\text { Flour particle } \\
\text { size }\end{array}$} & \multicolumn{3}{|c|}{ Farinograf değerleri } & \multicolumn{3}{|c|}{ Ekstensograf değerleri } \\
\hline & $\begin{array}{c}\mathrm{Su} \\
\text { absorbsiyonu } \\
(\%) \\
\text { Water } \\
\text { absorption (\%) }\end{array}$ & $\begin{array}{l}\text { Gelişme } \\
\text { süresi (dk) } \\
\text { Dough } \\
\text { depelopment } \\
\text { time (min) }\end{array}$ & $\begin{array}{l}\text { Stabilite } \\
\text { (dk) } \\
\text { Stability } \\
\text { (min) }\end{array}$ & $\begin{array}{c}\text { Enerji } \\
\left(\mathrm{cm}^{2}\right) \\
\text { Area }\left(\mathrm{cm}^{2}\right)\end{array}$ & $\begin{array}{c}\text { Uzamaya } \\
\text { karş1 } \\
\text { direnç } \\
(\mathrm{BU}) \\
\text { Resistance } \\
\text { to } \\
\text { extension } \\
(B U) \\
\end{array}$ & $\begin{array}{l}\text { Uzayabilirlik } \\
\text { (mm) } \\
\text { Exstensibility } \\
(\mathrm{mm})\end{array}$ \\
\hline Kontrol & $54.1 \pm 0.05^{\mathrm{ab}}$ & $2.2 \pm 0.05^{\mathrm{a}}$ & $4.2 \pm 0.15^{b}$ & $130 \pm 0.0^{a}$ & $1062 \pm 41^{a}$ & $99 \pm 0.00^{\mathrm{b}}$ \\
\hline $\begin{array}{l}150-250 \mu \\
\text { aras1 }\end{array}$ & $53.2 \pm 0.10^{\mathrm{b}}$ & $1.7 \pm 0.00^{\mathrm{b}}$ & $11.1 \pm 0.05^{\mathrm{a}}$ & $111 \pm 1.5^{\mathrm{b}}$ & $832 \pm 37^{b}$ & $105 \pm 1.50^{\mathrm{b}}$ \\
\hline $150 \mu$ altı & $54.8 \pm 0.40^{\mathrm{a}}$ & $1.7 \pm 0.00^{\mathrm{b}}$ & $3.5 \pm 0.25^{\mathrm{c}}$ & $129 \pm 0.25^{\mathrm{a}}$ & $758 \pm 16^{b}$ & $125 \pm 2.52^{\mathrm{a}}$ \\
\hline
\end{tabular}

a Aynı sütundaki farklı harfler istatistiksel olarak farklıdır. $(P<0.05)$

a Values in the same column followed by different letters are significantly different $(P<0.05)$ 
Partikül boyutu hamur formülasyonlarının gelişme sürelerini etkilememiş olup bu süre, formülasyonunda $150-250 \mu$ arasi ve $150 \mu$ altı un kullanılan hamurlar için $1.7 \mathrm{dk}$ ve kontrol örneği için ise 2.2 dak olarak belirlenmiştir. Ayrıca 150$250 \mu$ arasi un kullanılarak hazırlanan ekmek hamurlarının yumuşama derecesinin daha düşük (54 BU) buna karşın stabilitesinin daha yüksek (11.1 dak) olduğu tespit edilmiştir. Diğer formülasyonlarda oransal olarak daha fazla su kullanılmasi hamurların stabilitesi üzerine olumsuz bir etkide bulunmuştur. Tüm sonuçlar birlikte değerlendirildiğinde, büyük un partikül boyutunun daha düşük su absorbsiyon değerine sahip olduğu buna karşın hamur stabilitesini arttırdığı tespit edilmiştir. Benzer sonuçlar başka araştırmacılar tarafindan da tespit edilmiş olup Protonotariou vd. (2015), ileri derecede ögütülen tam buğday unlarının stabilite değerinin, kontrol örneklerine göre daha düşük olduğunu rapor etmiştir. $\mathrm{Bu}$ durumun ise ileri ögütme sonucu ortaya çıan isının gluten ağ yapisına zarar vermesinden ve protein yapisinı zayiflatmasindan kaynaklanabileceği ortaya konulmuştur. Moreira vd. (2010) kestane unu içeren hamur formülasyonlarında hamur stabilitesinin un partikül boyutundaki artış ile doğru orantıll olarak azaldığını rapor etmiştir.

Ekstensograf verileri değerlendirildiğinde 150-250 $\mu$ arasi boyuttaki unlar ile hazırlanan hamurların enerji değerinin, diğer örneklere göre daha düşük olduğu tespit edilmiştir. Un partikül boyutunun azalması hamurların uzamaya karşı gösterdiği direnci azaltırken uzayabilme kapasitesini ise arttırmıştır. Böylece un partikül boyutunun azalması hamurun işlenebilirliğini ve elastikiyetini artırmıştır. Maksimum direnç ise uzamaya karşı direnç ile benzer şekilde en yüksek kontrol örneğinde tespit edilmiştir.

\section{Farklı un partikül boyutunun ekmeğin renk değerleri üzerine etkisi}

Ekmek örneklerinin $L^{*}, a^{*}$ ve $b^{*}$ renk değerlerindeki değişim Çizelge 2'de verilmiştir. Farklı un partikül boyutunun ekmek kabuğunun $\mathrm{L}^{*}$ ve $\mathrm{b}^{*}$ renk değerleri üzerine istatistiksel olarak önemli $(P<0.05)$ bir etkisinin olduğu ancak a değeri üzerine önemli $(P>0.05)$ bir etkisinin olmadığ tespit edilmiştir.

Çizelge 2. Farklı un partikül boyutunun ekmeğin fiziksel özellikleri üzerine etkisi Table 2. The effect of flour particle size on the physical properties of bread

\begin{tabular}{|c|c|c|c|c|c|c|c|}
\hline \multirow{2}{*}{$\begin{array}{l}\text { Un } \\
\text { boyutu } \\
\text { Flour } \\
\text { particle size }\end{array}$} & \multirow{2}{*}{$\begin{array}{c}\text { Spesifik } \\
\text { hacim } \\
\left(\mathrm{cm}^{3} / \mathrm{g}\right) \\
\text { Specific volume } \\
\left(\mathrm{cm}^{3} / \mathrm{g}\right)\end{array}$} & \multicolumn{3}{|c|}{$\begin{array}{c}\text { Ekmek kabuğunun renk değerleri } \\
\text { Colour values of bread crust }\end{array}$} & \multicolumn{3}{|c|}{$\begin{array}{l}\text { Ekmek içi renk değerleri } \\
\text { Colour values of bread crumb }\end{array}$} \\
\hline & & $\mathrm{L}^{*}$ & $a^{*}$ & $b^{*}$ & $\mathrm{~L}^{*}$ & $a^{*}$ & $b^{*}$ \\
\hline Kontrol & $3.59 \pm 0.08^{b}$ & $53.28 \pm 0.27^{a}$ & $11.76 \pm 0.39^{a}$ & $28.22 \pm 0.27^{\mathrm{a}}$ & $71.84 \pm 0.43^{a}$ & $-0.77 \pm 0.01^{\mathrm{a}}$ & $16.50 \pm 0.33^{\mathrm{a}}$ \\
\hline $\begin{array}{l}150-250 \mu \\
\text { aras1 }\end{array}$ & $4.04 \pm 0.30^{\mathrm{a}}$ & $46.90 \pm 0.69^{a}$ & $12.89 \pm 0.64^{a}$ & $25.16 \pm 0.16^{\mathrm{ba}}$ & $70.04 \pm 0.72^{a}$ & $-1.07 \pm 0.07 a$ & $16.33 \pm 0.62^{a}$ \\
\hline $150 \mu$ altı & $3.25 \pm 0.24^{c}$ & $39.83 \pm 2.48^{b}$ & $12.42 \pm 1.41^{a}$ & $18.64 \pm 2.89^{\mathrm{b}}$ & $69.18 \pm 1.99^{a}$ & $-1.09 \pm 0.11^{\mathrm{a}}$ & $15.81 \pm 0.52^{\mathrm{a}}$ \\
\hline
\end{tabular}

a Aynı sütundaki farklı harfler istatistiksel olarak farklıdır. $(P<0.05)$

a Values in the same column followed by different letters are significantly different $(P<0.05)$

L* renk değeri 0 ile 100 arasında değişmekte ve gidanın parlaklığ1 hakkında fikir vermektedir. Çalışmada üretilen ekmek örneklerinin kabuk rengi 39.83 ile 53.28 değeri arasında değişmekte olup en düşük $L^{*}$ değeri, $150 \mu$ altında un partikül boyutuna sahip ekmeklerde tespit edilmiştir. Partikül boyutunun küçülmesi ile birlikte nişasta zedelenmesi artmakta ve dekstrin gibi Maillard reaksiyonu aktivitesi yüksek şekerler ortamda birikmektedir. Fırın sıcaklığında ekmek ortamında bulunan serbest amino asitler ve şekerler Maillard reaksiyonlarına girerek esmer renkli melanoidin bileşiklerini oluşturmaktadır. Bu nedenle küçük partikül boyutuna sahip unlar ile üretilen ekmeklerin kabukları daha koyu bir renge sahip olmaktadır. Yapılan bir çalışmada da benzer sonuçlar elde edilmiş olup formülasyonda düşük partikül boyutlu un oranı arttıkça pişirilen ekmeklerin $L^{*}$ değerinde bir düşüş tespit edilmiştir (Vouris vd., 2018). 
$\mathrm{b}^{*}$ renk değeri gıdaların sarı (+) ve mavi (-) renk yoğunluğu hakkında bilgi vermektedir. Çalışmada üretilen ekmek örneklerinin $b^{*}$ renk değeri 18.64 ile 28.22 arasinda değişmekte olup en düşük değer, $150 \mu$ altında un partikül boyutuna sahip ekmeklerde tespit edilmiştir. Bu durumun ise yine parlaklık değerini etkileyen nedenlerden kaynaklanmış olabileceği düşünülmektedir. Ekmeklerin $a^{*}$ renk değeri ise ortalama 12.36 olarak tespit edilmiştir. Protonotariou vd. (2015) partikül boyutu azalmasıyla birlikte ekmeklerin L* değerinin azaldığını, buna karşın kırmızılık ve sarılık değerlerinin arttığını tespit etmiştir.

Yapılan renk analizi sonucunda ekmek içi L*, a* ve $b^{*}$ değerlerinin, farklı un partikül boyutundan istatistiksel olarak önemli $(P>0.05)$ düzeyde etkilenmediği ve bu değerlerin ise sırasıyla 70.35, 0.98 ve 16.21 olduğu tespit edilmiştir.

\section{Farklı un partikül boyutunun ekmeğin spesifik hacim değerleri üzerine etkisi}

Ekmek örneklerinin spesifik hacim değerlerindeki değişim Çizelge 2'de verilmiştir. Un partikül boyutunun, ekmeklerin spesifik hacim değerleri üzerinde istatistiksel olarak önemli $(P<0.01)$ bir etkisinin bulunduğu tespit edilmiştir.

$150 \mu$ altında partikül boyutuna sahip un örnekleri ile üretilen ekmeklerin spesifik hacim değeri 3.25 $\mathrm{cm}^{3} / \mathrm{g}$ ile en düşük değeri alırken, daha büyük partikül boyutuna sahip un örnekleri ile üretilen ekmeklerin spesifik hacim değeri $4.04 \mathrm{~cm}^{3} / \mathrm{g}$ olarak tespit edilmiştir. Jet değirmenlerde ögütülerek partikül boyutu küçültülen unların formülasyonda kullanılması ile ekmek spesifik hacim değerinin azaldığını rapor eden benzer çalışmalar mevcuttur (Protonotariou vd., 2015; Vouris vd., 2018). Bu durumun nedeni ise un partikül boyutunun küçülmesi ile birlikte su absorbsiyon değerinin artması ve sonuç olarak daha yüksek viskoziteye sahip ekmek hamurunun elde edilmesi olarak gösterilmektedir (Vouris vd., 2018). Tam buğday unu kullanılarak gerçekleştirilen çalışmalarda bunun nedeninin kepek fraksiyonunun partikül boyutunun ileri düzeyde küçülmesi ve bu parçacıkların gluten arabinoksilan interaksiyonunu arttırmasindan kaynaklandığı rapor edilmiştir (Noort vd., 2010). Ayrıca glutensiz ekmek üretiminin amaçlandığı bir başka çalısmada da daha küçük partikül boyutuna sahip pirinç ve mısır unu ile üretilen ekmeklerin gaz tutma kapasitesinin oldukça az olduğu bildirilmiştir (De la Hera vd., 2013; Hera vd., 2013).

\section{Farklı un partikül boyutunun ekmeğin tekstürel özellikleri üzerine etkisi}

Ekmek örneklerinin sertlik, esneklik, iç yapışkanlık, sakızımsılık, çiğnenebilirlik ve elastikiyet gibi tekstürel özelliklerine ait veriler Çizelge 3'te verilmiştir. İstatistiksel analiz sonuçlarına göre farklı un partikül boyutu ve depolama süresi ekmek örneklerinin sertlik, çiğnenebilirlik değerleri üzerine önemli $(P<0.01)$ bir etkide bulunurken elastikiyet, iç yapışkanlık ve esneklik değerlerini etkilememiştir $(P>0.05)$.

Çizelge 3. Farklı un partikül boyutunun depolama süresince ekmeğin tekstürel özellikleri üzerine etkisi Table 3. The effect of flour particle size on the texture of bread during storage

\begin{tabular}{lcccccc}
\hline $\begin{array}{l}\text { Un boyutu } \\
\text { Flour particle size }\end{array}$ & $\begin{array}{c}\text { Depolama } \\
\text { Storage }\end{array}$ & $\begin{array}{c}\text { Sertlik (g) } \\
\text { Hardness }(g)\end{array}$ & $\begin{array}{c}\text { Elastikiyet } \\
\text { Springiness }\end{array}$ & $\begin{array}{c}\text { İç yapişkanlik } \\
\text { Cobesiveness }\end{array}$ & $\begin{array}{c}\text { Çiğnenebilirlik } \\
\text { Cheweness }\end{array}$ & $\begin{array}{c}\text { Esneklik } \\
\text { Resilience }\end{array}$ \\
\hline \multirow{2}{*}{ Kontrol } & 0. gün & $822 \pm 44.86^{\mathrm{bB}}$ & $1.02 \pm 0.02^{\mathrm{aA}}$ & $0.82 \pm 0.00^{\mathrm{aA}}$ & $793 \pm 56^{\mathrm{bAB}}$ & $0.32 \pm 0.02^{\mathrm{aA}}$ \\
& 6.gün & $2999 \pm 96.34^{\mathrm{aA}}$ & $0.96 \pm 0.00^{\mathrm{aA}}$ & $0.78 \pm 0.00^{\mathrm{bA}}$ & $2263 \pm 58^{\mathrm{aA}}$ & $0.33 \pm 0.01^{\mathrm{aA}}$ \\
\hline \multirow{2}{*}{$150-250 \mu$ aras1 } & 0. gün & $759 \pm 11.80^{\mathrm{bB}}$ & $1.11 \pm 0.14^{\mathrm{aA}}$ & $0.75 \pm 0.04^{\mathrm{aAB}}$ & $654 \pm 84^{\mathrm{bB}}$ & $0.27 \pm 0.00^{\mathrm{aA}}$ \\
& 6.gün & $2335 \pm 85.26^{\mathrm{aB}}$ & $0.96 \pm 0.01^{\mathrm{aA}}$ & $0.74 \pm 0.02^{\mathrm{aA}}$ & $1669 \pm 7.1^{\mathrm{aB}}$ & $0.30 \pm 0.01^{\mathrm{aA}}$ \\
\hline \multirow{2}{*}{$150 \mu$ alt1 } & 0. gün & $1467 \pm 126^{\mathrm{bA}}$ & $0.98 \pm 0.00^{\mathrm{aA}}$ & $0.64 \pm 0.06^{\mathrm{aB}}$ & $919 \pm 1.0^{\mathrm{bA}}$ & $0.23 \pm 0.04^{\mathrm{aA}}$ \\
& 6.gün & $3080 \pm 185^{\mathrm{aA}}$ & $0.88 \pm 0.02^{\mathrm{aA}}$ & $0.78 \pm 0.00^{\mathrm{aA}}$ & $2118 \pm 38^{\mathrm{aA}}$ & $0.36 \pm 0.04^{\mathrm{aA}}$ \\
\hline
\end{tabular}

a Aynı sütundaki farklı harfler istatistiksel olarak farklıdır. $(P<0.05)$. a-b, aynı un partikül boyutuna sahip unlar ile üretilen ekmek örneklerinin farklı günlerdeki tekstür parametresi ortalamalarına aittir. A-B, farklı un partikül boyutuna sahip unlar ile üretilen ekmek örneklerinin aynı günlerdeki testür parametresi ortalamalarına aittir.

a Values in the same column followed by different letters are significantly different $(P<0.05)$. a-b, within each column shows statistical differences between average of breads produced by same particle size with different sampling days. A-B, within each column shows statistical differences between average of breads produced by same sampling days with different particle size. 
Duncan Çoklu Karşılaştırma Testi sonuçlarına göre 6 günlük depolama sonunda, 150-250 $\mu$ aras1 un partiküllerinden üretilen ekmek örneklerinin sertlik değeri, kontrol ve $150 \mu$ altı un kullanılarak üretilen ekmeklere göre daha düşük olarak tespit edilmiştir. Buradan anlaşılacağı üzere un partikül boyutunun artması depolama süresince ekmeğin sertleşme oranını azaltmaktadır. Ayrıca, tüm ekmek çeşitlerinin sertlik değeri 6 günlük depolama süresince yaklaşık 2.7 katına çıkmıştır. Jet ögütme tekniği ile partikül boyutları 21-75 $\mu$ arasına küçültülen ekmeklik unlar ile yapılan bir çalışmada ekmek formülasyonunda düşük partikül boyutlu un oranının artmasıyla birlikte ekmek içi ve kabuğunun sertlik değeri artmış çiğnenebilirlik ve elastikiyet özellikleri ise kötüleşmiştir (Vouris vd., 2018). Yine jet ögütme ile farklı partikül boyutlarına sahip tam buğday ekmeklerinin tekstür ölçümleri sonucunda daha düşük boyuta sahip unlar ile elde edilen ekmeklerin sertlik değerinin kontrol örneklere göre daha yüksek olduğu belirlenmiştir (Protonotariou vd., 2015). Depolama sirasında meydana gelen nişasta retrogradasyonu sonucu ürünün daha sert ve katı bir görünüm kazandiğı bilinmektedir (Limanond vd., 2002).

Sertlik parametresi gibi depolama sonunda en düşük çiğnenebilirlik değerleri de 150-250 $\mu$ aras1 un partiküllerinden üretilen ekmek örneklerinde elde edilmiş olup bu değer 1669 g olarak tespit edilmiştir. Depolama süresince çiğnenebilirlik değerleri sırasıyla yaklaşık olarak 2.5 kat artış göstermiştir. Benzer sonuçlar başka araştırmacılar tarafindan da tespit edilmiş olup Vouris vd. (2018) 5 günlük depolama boyunca ekmek örneklerinin sertlik ve çiğnenebilirlik değerlerinin süre ile doğru orantilı olarak depolama sonuna kadar artış gösterdiğini bildirmiştir. Taze ekmekte bulunan amorf formdaki nişasta kristal formuna göre daha fazla su tutma kapasitesine sahip olup bu özellik ekmeğe yumuşaklık ve elastikiyet sağlamaktadır. Ancak bayatlama sirasinda retrogradasyonla birlikte nişasta polimerinin su tutma kapasitesi azalmakta ve kristalleşerek yeniden düzenlenmektedir. Nişastanın kaybettiği bu su ise gluten ağ1 tarafindan hapsedilmekte ve sonuç olarak ekmek içi sert elastik olmayan bir yap1 kazanmaktadır (Ercan ve Özkaya, 1985).

Ekmek örneklerinin ortalama elastikiyet, iç yapışkanlık ve esneklik değerleri ise sırasıyla, 0.99 , 0.75 ve 0.30 olarak tespit edilmiş olup depolama süresince de önemli bir değişim göstermemişlerdir.

\section{Farklı un partikül boyutunun ekmeğin nem kaybı üzerine etkisi}

Çizelge 4'de verilmiştir. Un partikül boyutu, ekmeklerin nem kaybını istatistiksel olarak önemli ( $P$ <0.01) düzeyde etkilemiştir (Çizelge 4). Depolama süresince ekmeklerde nem kaybı değerleri kontrol, $150-250 \mu$ arasi ve $150 \mu$ altı örnekler için sırasıyla \%14.92, 0.53 ve 6.72 olarak gerçekleşmiştir. Görüldügü üzere en düşük nem kayb1 150-250 $\mu$ arası boyuta sahip un ile üretilen ekmeklerde gerçekleşmiş olup bütüncül yapısını koruyan nişasta polimeri, formülasyonda bulunan suyu hidrate ederek ekmek dışına salınımını sınırlamıştır. Jet değirmende farklı partikül boyutlarında ögütülen unlar ile yapılan ekmek denemelerinde, daha düşük boyuta sahip ekmeklerin su salınımının daha fazla olduğu tespit edilmiştir (Protonotariou vd., 2015). Yapilan bir başka çalışmada ekmek su içeriğinin, nişastanın düzenli yapısının bozulmasında önemli bir rol oynadığ1 ortaya konulmuştur (Guo vd., 2018).

Çizelge 4. Farklı un partikül boyutunun depolama süresince ekmeğin nem kaybı ve bayatlama kinetiği üzerine etkisi

Table 4. The effect of flour particle size on the moisture loss and staling kinetics of bread during storage

\begin{tabular}{lcccccc}
\hline \multirow{2}{*}{$\begin{array}{l}\text { Un boyutu } \\
\text { Flour particle size }\end{array}$} & \multirow{2}{*}{\begin{tabular}{c} 
Nem kaybi $(\%)$ \\
\cline { 3 - 7 }
\end{tabular}} & \multicolumn{5}{c}{$\begin{array}{c}\text { Avrami model parametreleri } \\
\text { Avrami model parameters }\end{array}$} \\
\cline { 3 - 7 } & $14.91 \pm 2.03^{\mathrm{a}}$ & 3377.36 & $\mathrm{~T}_{0}$ & $\mathrm{n}$ & $\mathrm{k}$ & $\mathrm{R}^{2}$ \\
\hline Kontrol & $0.53 \pm 0.04^{\mathrm{c}}$ & 2568.77 & 263.99 & $1.60^{\mathrm{b}}$ & $0.32^{\mathrm{a}}$ & 0.98 \\
$150-250 \mu$ aras1 & $6.72 \pm 0.66^{\mathrm{b}}$ & 4352.53 & 441.59 & $1.60^{\mathrm{b}}$ & $0.24^{\mathrm{a}}$ & 0.94 \\
$150 \mu$ alt1 & $6.76^{\mathrm{a}}$ & $0.13^{\mathrm{b}}$ & 0.93 \\
\hline
\end{tabular}

a Aynı sütundaki farklı harfler istatistiksel olarak farklıdır. $(P<0.05)$

a Values in the same column followed by different letters are significantly different $(P<0.05)$. 
Farklı un partikül boyutunun ekmeğin bayatlama kinetiği üzerine etkisi

Depolama süresince ekmek içi sıkilık değerlerindeki değişimler genellikle Avrami matematiksel modeli kullanılarak değerlendirilmektedir. Bu eşitlik belirli katı bir matrisde meydana gelen nişasta kristalizasyon derecesinin değerlendirilmesinde kullanılmakta olup devam eden kristalizasyon, zamanın üstel ters fonksiyonu olarak ifade edilmektedir (Armero ve Collar, 1998). $\mathrm{T}_{0}$ değeri pişirme sonundaki ekmek örneklerinin sıkılık değerini, $T_{\infty}$ değeri depolama sonundaki ekmek örneklerinin sık1lı değerini, k kristalizasyon oran sabitini, n Avrami model katsayısını ve $\mathrm{R}^{2}$ ise modelin uyumluluğunu ifade etmektedir. Sonuçların modele uygulanması sonucunda elde edilen $\mathrm{k}$ değeri ekmek içinin sıkılık oranını göstermekte olup bu değerin düşük olması sertleşme sürecinin dolayısı ile bayatlamanın daha yavaş ilerlediğini ifade etmektedir (Amigo vd., 2016; Russell, 1983).

Non-lineer regresyon analiz sonucunda elde edilen Avrami model parametreleri Çizelge 4'de verilmiştir. Depolama başında ve sonunda 150$250 \mu$ arasi un partiküllerinden üretilen ekmek örneklerinin sık1lk değerlerinin daha düşük olduğu görülmektedir. Bu bulgu tekstür analiz sonuçları ve nem kaybı değerleri ile uyumlu olarak değerlendirilmiştir.

Avrami katsayları incelendiğinde $150 \mu$ altı un partiküllerinden üretilen ekmek örnekleri 1.85 değeri ile en yüksek n değerini alırken 0.13 ile en düşük k değerini almıştır. Diğer bir taraftan ise kontrol örneklerinin hem $\mathrm{n}$ hem de $\mathrm{k}$ değerlerinin yüksek olması hızlı bir nişasta kristalizasyonunun gerçekleştiğini göstermektedir. $\mathrm{k}$ değerinin 1'e yaklaşması bayatlamanın çok hızlı olduğunu ve hatta depolamanın ilk gününde gerçekleştiğini göstermektedir (Amigo vd., 2016).

Genellikle k ve $\mathrm{n}$ değerlerinin her ikisinin birden yüksek olduğu gözlenmez. Bu durum ekmek içi bayatlamasının çok hızlı olduğu anlamına gelmektedir (Armero ve Collar, 1998). Kinetik hesaplama sonucunda yüksek $\mathrm{n}$ değeri sağlayan örneğin $\mathrm{k}$ değeri genellikle düşüktür. Bunun tam tersi durumlarda ise o ekmek örneği yavaş bayatlama özelliğine sahip olmaktadır (Armero ve
Collar, 1998). Bu durumda $150 \mu$ altı un örnekleri ile üretilen ekmekler hizlı bir kristalizasyon kinetiğine sahip iken $150-250 \mu$ aras1 unlar ile üretilen ekmeklerin nişasta kristalizasyon oranı daha yavaş olarak tespit edilmiştir. $\alpha$-amilaz ilavesinin, ekmeğin bayatlama süresini geciktirici etkilerinin araştırıldığ bir çalışmada Avrami model sabitleri olan $\mathrm{k}$ değerinin 0.26 ila 1.25 arasında değiştiği bildirilmiştir (Amigo vd., 2016).

\section{SONUÇLAR}

Temel bir besin maddesi olarak kabul edilen ekmeğin fiziksel raf ömrünün oldukça kısıtlı olmasi tüketimini olumsuz yönde etkilemektedir. Her y1 milyonlarca adet ekmek herhangi bir mikrobiyal bozulma olmaksızın bayatlama sonucu tazeliğini kaybettiğinden çöpe atılarak israf edilmektedir. Bu nedenle fazla miktarda üretilen ve tüketilen ekmeğin raf ömrünün uzatılması ülke ekonomisi açısından da önemli bir konudur.

Tüm analiz verileri birlikte değerlendirildiğinde un partikül boyutunun azalmasının ekmek hamurunun su tutma kapasitesinin yanında diğer bazı reolojik özelliklerini geliştirdiği ancak hamur stabilitesini azalttığ1 belirlenmiştir. Ekmek bayatlamasının Avrami kinetik model sonuçlarına göre ise $150 \mu$ altı un örnekleri ile üretilen ekmeklerde nişasta kristalizasyon hızının 150-250 $\mu$ arası un örnekleri ile üretilen ekmeklere kıyasla daha yüksek olduğu dolayısıyla bayatlamanın daha hızlı gerçekleştiği belirlenmiştir. Elde edilen bu verilerin ekmeklerin nem kayb1 ve tekstür sonuçları ile de uyumlu olduğu değerlendirilmiştir.

Sonuç olarak ekmek üretiminde kullanılacak olan unların aşırı düzeyde ögütülerek partikül boyutunun küçültülmesi ekmek bayatlama oranını arttırmaktadır. Bu nedenle bir taraftan bayatlama oranını azaltacak diğer bir taraftan ise ekmeğin alışılagelmiş renk ve hacim gibi kalite özelliklerini arttıracak optimum un partikül boyutu seviyelerinin belirlenmesini gerektiren ileri düzey çalışmalar yapılmalıdır.

\section{KAYNAKLAR}

AACC. (2000). American Association of Cereal Chemists, Method 54-21.01, Method 54-10.01, Method 74-10.02, Method 44-19.01, Method 1005.01. The Association, Minnesota, USA. 
Amigo, J. M., Alvarez, A. D., Engelsen, M. M., Lundkvist, H., Engelsen, S. B. (2016). Staling of white wheat bread crumb and effect of maltogenic alpha-amylases. Part 1: Spatial distribution and kinetic modeling of hardness and resilience. Food Chem, 208: 318-325.

Armero, E., Collar, C. (1998). Crumb firming kinetics of wheat breads with anti-staling additives. J Cereal Sci, 28(2): 165-174.

Atwell, W.A., Hood, L.F., Lineback, D. R., Varriano-Marston, E., Zobel, H.F. (1988). The terminology and methodology associated withbasic starch phenomena. Cereal Foods World, 33:306-311.

Correa, M. J., Ferrero, C. (2015). A comparative study of commercial modified celluloses as bread making additives. Int J Food Prop, 18(4): 849-861.

De la Hera, E., Talegón, M., Caballero, P., Gómez, M. (2013). Influence of maize flour particle size on gluten-free breadmaking. J Sci Food Agri, 93(4): 924-932.

Elgün, A., Ertugay, Z. (2002). Tahıl işleme teknolojisi. Atatürk Üniversitesi Yaynlar, Erzurum, $411 \mathrm{~s}$

Ercan, R., Özkaya, H. (1985). Ekmeğin Bayatlamas1. Gida, 10(6): 335-340.

Fadda, C., Sanguinetti, A. M., Del Caro, A., Collar, C., Piga, A. (2014). Bread staling: Updating the view. Comp Rev Food Sci Food Safety, 13(4:, 473-492.

Gambaro, A., Varela, P., Gimenez, A., Aldrovandi, A., Fiszman, S. M., Hough, G. (2002). Textural quality of white pan bread by sensory and instrumental measurements. J Texture Studies, 33(5): 401-413.

Guo, P., Yu, J. L., Wang, S. J., Wang, S., Copeland, L. (2018). Effects of particle size and water content during cooking on the physicochemical properties and in vitro starch digestibility of milled durum wheat grains. Food Hydrocoll, 77: 445-453.

Hera, E. d. 1., Martinez, M., Gómez, M. (2013). Influence of flour particle size on quality of gluten-free rice bread. LWT - Food Sci Tech, 54(1): 199-206.

Ho, L. H., Aziz, N. A. A., Azahari, B. (2013). Physico-chemical characteristics and sensory evaluation of wheat bread partially substituted with banana (Musa acuminata X balbisiana cv. Awak) pseudo-stem flour. Food Chem, 139(1-4): 532-539.

Leon, A. E., Barrera, G. N., Perez, G. T., Ribotta, P. D., Rosell, C. M. (2006). Effect of damaged starch levels on flour-thermal behaviour and bread staling. Eur Food Res Tech, 224(2):187-192.

Limanond, B., Castell-Perez, M. E., Moreira, R. G. (2002). Modeling the kinetics of corn tortilla staling using stress relaxation data. J Food Eng, 53(3):237-247.

Moreira, R., Chenlo, F., Torres, M. D., Prieto, D. M. (2010). Influence of the particle size on the rheological behaviour of chestnut flour doughs. $J$ Food Eng, 100(2): 270-277.

Noort, M. W. J., van Haaster, D., Hemery, Y., Schols, H. A., Hamer, R. J. (2010). The effect of particle size of wheat bran fractions on bread quality - Evidence for fibre-protein interactions. J Cereal Sci, 52(1): 59-64.

Protonotariou, S., Mandala, I., Rosell, C. M. (2015). Jet milling effect on functionality, quality and in vitro digestibility of whole wheat flour and bread. Food Bioprocess Tech, 8(6): 1319-1329.

Russell, P. L. (1983). A kinetic-study of bread staling by differential scanning calorimetry and compressibility measurements - the effect of different grists. J Cereal Sci, 1(4): 285-296.

Smith, P. R., Johansson, J. (2004). Influences of the proportion of solid fat in a shortening on loaf volume and staling of bread. J Food Process Preserv, 28(5): 359-367.

Vouris, D. G., Lazaridou, A., Mandala, I. G., Biliaderis, C. G. (2018). Wheat bread quality attributes using jet milling flour fractions. $L W T$ Food Sci Tech, 92: 540-547. 